\title{
SEXUAL AND MENSTRUAL PRACTICES: RISKS FOR CERVIX CANCER
}

\section{Johanna E Maree}

D Cur

Head of Department, Department of Nursing, Tshwane University of Technology, Tshwane

Corresponding author: mareeje@tut.ac.za

\section{Susan CD Wright}

D Tech Nursing

Senior lecturer, Tshwane University of Technology, Tshwane

Keywords: cervix cancer; sexual practices; menstrual practices

\begin{abstract}
Cervix cancer is the cancer that causes most female deaths in South Africa. Little is known about the sexual and menstrual practices in high-risk communities in South Africa. Knowledge of the risks inherent in these practices might lead to changed behaviour. The purpose of this study was to investigate if there are inherent risk factors for cervix cancer in the Black women's sexual and menstrual practices that could result in an increased incidence to provide an evidence base for future interventions. The design of the study was an exploratory, descriptive, contextual, quantitative survey. The context of the study was two urban areas in the Tshwane Metropolis. The target population was women from the age of 18 years in Ga-Rankuwa and Soshanguve extension 12. The sampling method used was convenient sampling $(n=279)$. A structured interview was conducted due to the high rate of illiteracy found amongst the women. The data were summarised using descriptive statistics. The results of the study highlight several risks that could increase the women's chance to develop cervix cancer. The identified risks are inherent in their socio-economic situation, knowledge and awareness of cervix cancer, and practices during menstruation.
\end{abstract}

\section{OPSOMMING}

Servikskarsinoom is verantwoordelik vir die meeste kankersterftes in vroue in Suid Afrika. Min is bekend aangaande die seksuele- en menstruasiepraktyke in hoë risiko gemeenskappe in Suid-Afrika. Kennis van risiko's wat in hierdie praktyke verskuil is mag tot gedragverandering lei. Die fokus van dié studie was om te bepaal of daar verskuilde risiko's vir servikskarsinoom in Swart vroue se seksuele- en menstruasiepraktyke is. Die navorsingsontwerp vir die studie was 'n ondersoekende, kwantitatiewe opname. Die konteks van die studie was twee stedelike gebiede in die Tshwane Metropool. Die populasie was vroue vanaf die ouderdom van 18 jaar in Ga-Rankuwa en Soshanguve uitbreiding 12. ' $n$ Gerieflikheidsteekproef is gedoen $(n=279)$. As gevolg van die hoë peil van ongeletterdheid, is data deur middel van 'n gestruktureerde onderhoud ingesamel en met behulp van beskrywende statistiek opgesom en weergegee. Die resultate van die studie het verskeie risiko's wat die kans vir servikskarsinoom verhoog, getoon. Hierdie risiko's hou verband met die vroue se sosio-ekonomiese situasie, hul kennis en bewustheid van servikskarsinoom en praktyke tydens menstruasie. 


\section{BACKGROUND AND RATIONALE}

Cervix cancer is cited as the most prevalent cancer in women in developing countries (Cassidy, Bissett \& Spence, 2002:426), and the cancer that causes the most mortality among South African women. The incidence rate of cervix cancer in South Africa varies according to population group. The annual incidence per 100000 for cervix cancer in Black women is 40 compared to 9 in White women (CANSA, 2004). The relationship between environmental, economic, sociological and ethnological factors might indicate the aetiology for the high incidence of cervix cancer in Black women. The focus of this article is to report on research done to determine if there are inherent risk factors for cervix cancer in the Black woman's menstrual and sexual practices that could result in an increased incidence of cervix cancer.

Cancer of the cervix is caused by the human papillomavirus (HPV), the most common sexually transmitted infection. Most HPV infections become undetectable within one to two years after the initial infection (Schiffman \& Castle, 2003:930). Several factors increase the risk of the HPV infection developing into cervix cancer. For example, the cervical epithelium of the sexually active teenager has an increased susceptibility to the HPV and as such, the early onset of sexual intercourse is one of the factors associated with the prevalence of cervix cancer (Cassidy, Bissett \& Spence, 2002:426). Factors such as smoking, multi-parity and long term use of oral contraception have also been found to increase the risk of persistence and progression of cervix cancer. Other sexually transmitted infections, chronic inflammation and nutritional factors likewise play a role in the development of cervix cancer. Non-barrier forms of contraception and poverty are also linked to cervix cancer (Schiffman \& Castle, 2003:930). Though these facts might be known to health care professionals, the general population seems to not be knowledgeable about cervix cancer.

A significant section of South African women are still uninformed regarding cervix cancer. In a study conducted in 2002 in Durban, it was found that up to 65\% of women did not have any knowledge about cervix cancer or a Papanicolaou (Pap) smear (Leeman, 2002). Also, although women may be aware of cancer of the cervix, not all are aware of the link between cervix can- cer and sex (Waller, McCaffery, Nazroo \& Wardel, 2005:265). Unfortunately, a woman's risk of cervix cancer may depend less on her own sexual behaviour than that of her male partner, as men can acquire penile HPV through other sexual contacts (Castellsague, Bosch \& Munoz, 2003:S345).

Washing the genitalia infrequently during menstruation also increases the risk for cervical cancer (Herrero, Brinton, Reeves, Brenes, Tenorio, De Briton, Gaitan, Garcia \& Rawls, 1990:380). In impoverished communities, menstruation is often poorly managed due to the lack of water, proper sanitation and affordable sanitary materials (Gichaga, 2000:6). In an Indian study conducted on menstrual practices, it was found that unhygienic practices are employed during menstruation, with old cloth mainly being used during menstruation (Drakshayani \& Venka, 1994:139). Knowledge of the risks inherent in these practices may lead to changed behaviour.

Cancer of the cervix is largely preventable. A primary prevention approach is needed to promote a healthy lifestyle and behaviours that will minimise the risk of developing cervix cancer (Shephard, Weston, Persman \& Napuli, 2000:CD001035). In order to develop health promotion intervention strategies aimed at the prevention of cervix cancer, it is necessary for the registered professional nurse to know and understand unsafe behaviours and the risk factors for cervix cancer.

\section{PROBLEM STATEMENT AND RE- SEARCH QUESTION}

Little is known about the hygiene practices during menstruation and sexual practices in high-risk communities in South Africa. The modern practice of engaging in sex during menses is associated with the development of sexual transmitted diseases such as chlamydia, gonorrhoea and HIV infection, which in turn are associated with cervix cancer (Ben-Noun, 2003:101). Sexual practices to enhance the pleasure of the male partner by drying the vagina with newspaper or snuff have been reported (Msiza, 2005) but not yet investigated.

To enable the Department of Nursing Science to develop and implement health promotion intervention strategies aimed at decreasing the risk of cervix cancer 
among Black women, the following question was posed: Are there inherent risk factors in the sexual and menstrual practices of Black women living in Tshwane, as well as in their level of knowledge and beliefs regarding cervix cancer, that may increase their risk of developing cervix cancer?

\section{PURPOSE OF THE STUDY}

The purpose of the study was to determine if there are inherent risk factors in the sexual and menstrual practices of Black women, as well as in their level of knowledge and their beliefs regarding cervix cancer, that may increase their risk of developing cervix cancer.

\section{THEORETICAL FRAMEWORK}

The Self-Care Deficit Nursing Theory developed by Dorothea Orem is one of the nursing theories commonly used in nursing practice (Berbiglia, 2006:255). Orem's self-care theory is based on the belief that all individuals have a need for self-care, and that nursing can assist the person to meet these self-care needs. Selfcare refers to the individual's power or learned ability to perform self-care and includes knowledge, skill and motivation to perform self-care actions to promote life, health and well-being as well as prevent disease and disability. Various factors can influence self-care, including the age of the person, health status, pattern and response to stimuli, and values and goals.

According to Orem (Berbiglia, 2006:255) a self-care deficit exists when a person is unable to meet personal self-care needs and the role of nursing is to give direct assistance to the person that is unable to perform self-care. Three action systems are described in which nurses assist individuals until self-care needs are met.

These systems are:

- Wholly compensatory, where the individual is not able to meet any needs and the nurse must meet all the care needs of the individual. The client's action is limited whilst the nursing action is intense as total care is provided.

- Partially compensatory, where the client is able to meet some care needs but still requires assistance form the nurse. The nurse's and the client's actions are shared and therefore the responsibility is shared.

- $\quad$ Supportive-educative, where the client is able to perform self-care but requires supportive education. The client's action is intense and supported by the nurse's action. The client is primarily responsible for personal health while the nurse acts as consultant (Edmond, 2003:65).

It is the premise of the authors that a self-care deficit can occur from two perspectives. If the client is not knowledgeable about possible risks in her menstrual and sexual practices, she cannot take responsibility for her personal health. Conversely, if the registered professional nurse has no knowledge of the social determinants or health risks that are occurring in a community, the nurse cannot perform a supportive, educative role when a teachable moment occurs. Working in the community requires from the registered professional nurse an understanding of the social determinants of health risks within that community, and therefore an investigation was launched to determine if there are health related practices that could increase the women's risk of developing cervix cancer.

\section{Central theoretical statement}

Understanding the social determinants of these health related practices will enable the registered professional nurse to fulfil her supportive-educative role in the prevention of cervix cancer.

\section{STUDY METHODS AND DESIGN}

The research methods and design will be described in terms of the context, design, population, data gathering, and data analysis.

\section{Context}

A contextual study was performed. The context of the study was two urban areas in Tshwane. A significant proportion of the population in both areas are unemployed, poor and living in informal settlements. Houses often lack running water, and water is collected from a central tap.

\section{Research design}

The design of the study was a quantitative survey (Burns 
\& Grove, 2001:256). A survey is used to measure phenomena in a group. The menstrual and sexual practices as well as the knowledge and beliefs of women living in the two areas in Tshwane regarding cervix cancer were measured.

\section{Population}

The target population was Black women from the age of 18-60 years in Ga-Rankuwa and Soshanguve extension 12 . The sampling method used was convenient sampling (Burns \& Grove, 2001:374) as menstruating women from 18 years of age who were willing to participate were included in the study. Data were gathered for a period of three months. Adhering to statistical advice, the aim was to include at least 250 participants. The sample size was ultimately realised at 279 .

\section{Data gathering}

The data gathering method was a self-report using a structured interview. The interview was based on a structured questionnaire. The method was chosen due to a high rate of illiteracy found amongst the women and the need to have a broader representation of the health related practices than a qualitative approach would offer. The structured questionnaire consisted of four sections which included demographic and socio-economic data, knowledge and beliefs of cervix cancer, practices during menstruation, and sexual practices

The questions based on knowledge addressed the accepted knowledge of women regarding the risks and early signs and symptoms of cervix cancer. These questions, focussing on health practices, included protection during menstruation and hand and genital hygiene practices during menstruation. Beliefs were explored by means of an open-ended question that allowed the respondents to reflect on their beliefs of health care practices that might relate to cervix cancer.

The questions regarding sexual practices included known risk factors such as age of sexual debut, number of partners, intercourse during menstruation, protection during sexual intercourse (Brant, 1999:658), the wetness or dryness of the vagina during intercourse and how this was managed.

The questionnaire was pre-tested before the study on
10 women who were not part of the final study sample. The purpose of pre-testing was to determine if the questions were well understood and if the necessary data to address the objectives of the study were generated. No changes were made to the questionnaire after the pre-test.

To ensure anonymity and confidentiality, the questionnaire was numbered sequentially. Due to the sensitivity of the research, three older Setswana-speaking registered professional nurses were trained and appointed as field workers. The registered professional nurses were from the study area and well-known in the community. The field workers explained the purpose and method of the research to the women and obtained informed consent. The interview was conducted in English and Setswana, to ensure that the questions were well understood and the responses were directly documented on the questionnaire.

\section{Data analysis}

The data were coded and summarised using descriptive statistics (Burns \& Grove, 2001:179). Descriptive statistics enables the researcher to organise the data in ways that give meaning and facilitate insight. Data were analysed using the SPSS version 13.0 programme.

\section{VALIDITY AND RELIABILITY}

Several measures were taken to ensure the validity and reliability of the data. In an effort to promote trust and to prevent misunderstanding, the three fieldworkers who gathered the data were English and Setswana-speaking registered professional nurses. To answer the research question, the research was conducted by means of an exploratory, contextual, quantitative survey. Data were gathered during a structured interview using a questionnaire to guide the interview and to maintain structural coherence throughout the data, as well as reduce interviewer variability. The questionnaire was based on current scientific knowledge regarding the research theme, obtained through a literature review. A pre-test was conducted to ensure that the structured questionnaire was applicable and yielded the data necessary to address the purpose of the study. The fieldworkers were trained by the researchers before data-gathering commenced. 


\section{ETHICS}

The following ethical principles were applied in the study:

- Informed consent either written or verbal in the case of a respondent that was unable to write, was obtained from the participants before participation in the study.

- Anonymity and confidentiality was ensured, as the questionnaire was numbered sequentially without any identification of the person.

- Due to the sensitivity of the subject matter, the participants were interviewed in private. Participants could withdraw from the study at any time.

- The research proposal was approved by the Ethics Committee of the Tshwane University of Technology.

\section{RESULTS}

The discussion of the results was structured according to the questionnaire and will address the demographic and socio-economic data, as well as the knowledge of cervix cancer and sexual and menstrual practices of the participants.

\section{Demographic and socio-economic data}

The majority of the women (78.4\%) were younger than 40 years and of the Tswana socio-cultural group (58.8\%). The majority (62.7\%) were unemployed.
Running water in the house was available to only $56.6 \%$ and a flush toilet to $60.2 \%$. Electricity was available in $74.2 \%$ of households, $57 \%$ lived in a brick house, while $36.2 \%$ lived in informal housing.

\section{Knowledge and beliefs of cervix cancer}

The participants' general knowledge of cervix cancer was investigated. Only $44.8 \%$ knew of the existence of cervix cancer and slightly more, $49.8 \%$, knew that a Pap smear is used to diagnose cervix cancer. However, only $77.6 \%$ of the group who knew about cervix cancer also knew about the Pap smear. Of the women who did not know about cervix cancer, $27.3 \%$ professed knowledge of the Pap smear. Awareness of cervix cancer in terms of age groups indicates that from the age of 30 years and older, the level of awareness was approximately $50 \%$ in each group.

The participants' knowledge regarding the risks of cervix cancer through specific health related practices, was also investigated. These practices related to smoking, alcohol abuse, diet, early onset of intercourse, multiple sexual partners, history of sexually transmitted infections, non-barrier forms of contraception, and multiple pregnancies. The level of knowledge of the participants regarding the relationship between health related practices and the risk for cervix cancer is presented in Figure 1.

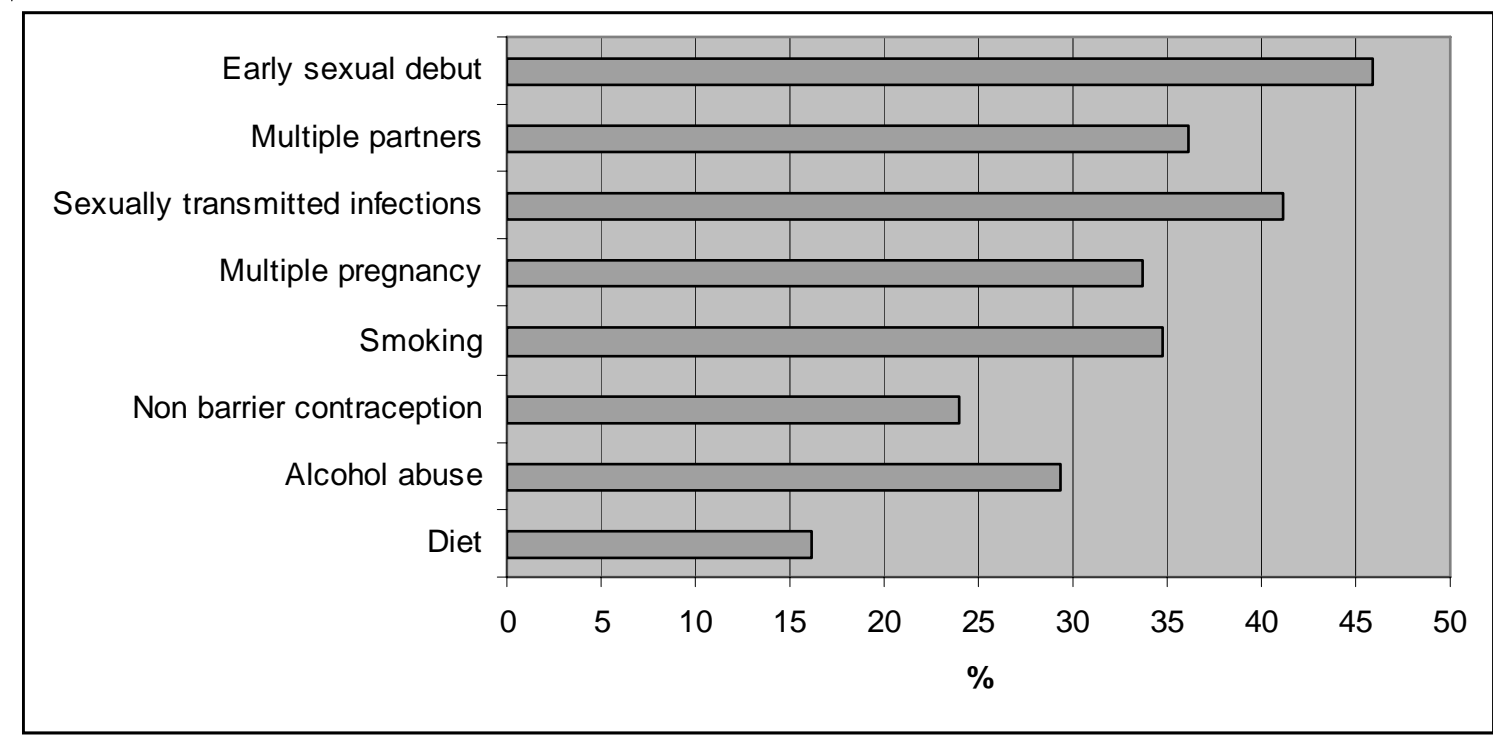

Figure 1: Knowledge of the relationship of health related practices and the risk for cervix cancer 
The health related practice in the group that was best known to be directly related to cervix cancer was early sexual debut (45.9\%). Secondly, sexually transmitted infections (41.2\%) were known as being a risk for cervix cancer while the least known risk factor was diet (16.1\%). An option in the questionnaire for participants to add 'other' health practices, was added to explore perceptions the participants might have had on health related practices and cervix cancer that were not given as options in the questionnaire. The most frequently mentioned beliefs about health related practices that are related to cervix cancer were: having sex during menstruation, using toilet paper during menstruation, and the role of genetic factors. Four participants mentioned witchcraft as being a potential risk factor for cervix cancer.

Knowledge of the early signs and symptoms of cervix cancer were also investigated. The early signs and symptoms mentioned by participants were: increased vaginal discharge, post-coital bleeding, intermenstrual bleeding, and post-menopausal bleeding. The results to this part of the questionnaire are presented in Figure 2.

More participants (36.6\%) knew that increased vaginal discharge is an early sign and symptom of cervix can- cer than any of the other three early signs and symptoms. The common denominator of the other three early signs and symptoms was abnormal bleeding, and the average awareness of bleeding being one of the early signs and symptoms of cervix cancer, was $25.4 \%$. Conversely, eight out of every ten women would not be concerned if they experienced abnormal bleeding. A possible reason for the lack of knowledge of abnormal bleeding as an early sign and symptom of cervix cancer could be that the participants expected cancer of the cervix to be painful although $8.2 \%$ of the group perceived pain to be an early sign of cervix cancer. Only $5 \%$ of the respondents acknowledged that they did not know any of the early signs and symptoms related to cervix cancer.

\section{Practices during menstruation}

Several commonly used practices during menstruation were investigated. These were sanitary protection, frequency of changing sanitary protection, re-use of sanitary protection, and hand and genital cleaning. Table 1 presents the results on external sanitary protection commonly used within the group. Though the majority (76.6\%) used sanitary towels, other more risky options were also mentioned as shown in Table 1.

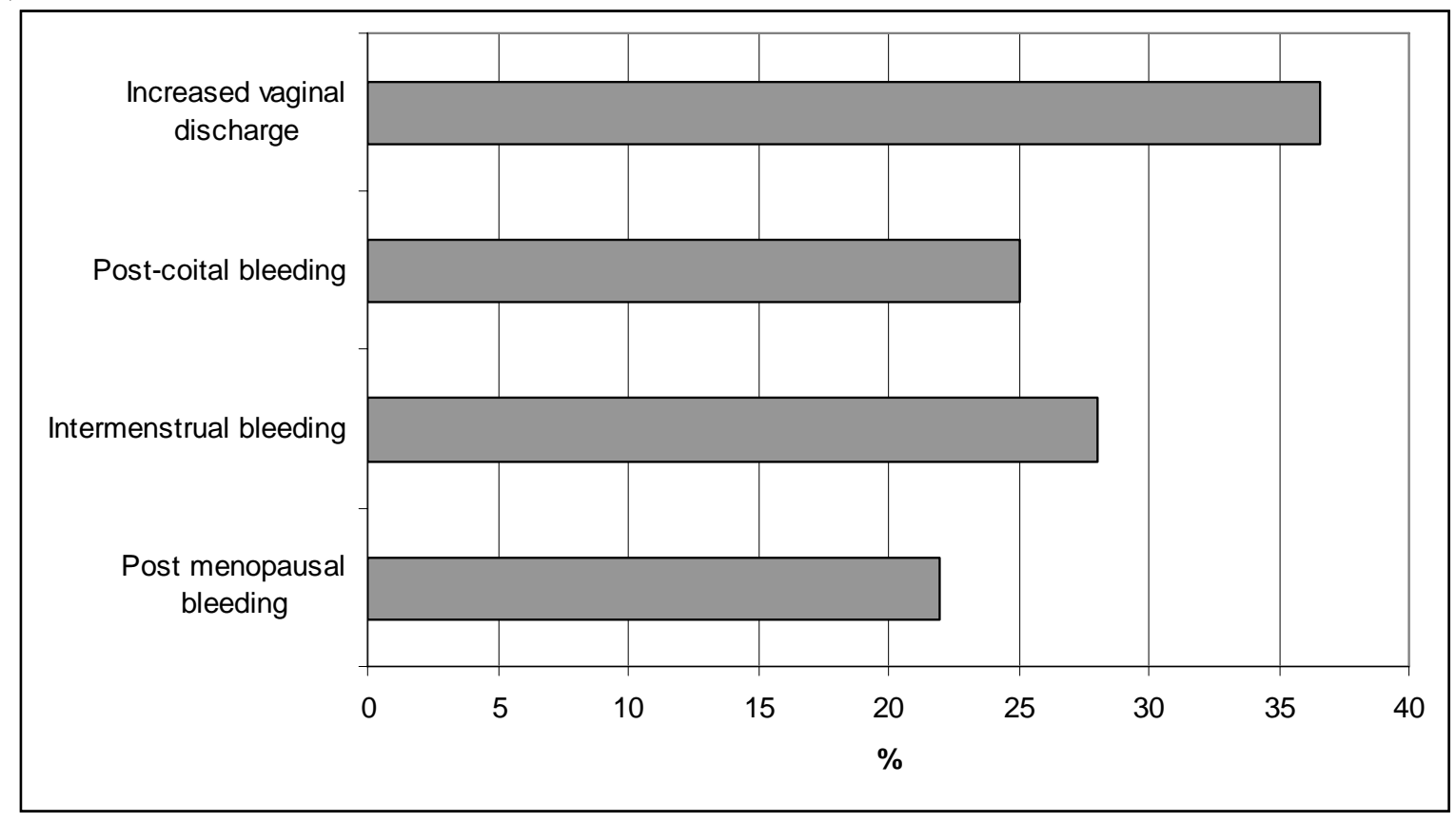

Figure 2: Knowledge of the early signs and symptoms of cervix cancer $(n=128)$ 
Table 1: External sanitary protection used

\begin{tabular}{|l|l|}
\hline External sanitary protection & \% indicating use \\
\hline Sanitary towels & 74.6 \\
\hline Cloth & 13.6 \\
\hline White toilet paper & 11.5 \\
\hline Coloured toilet paper & 6.5 \\
\hline Cotton wool & 3.6 \\
\hline Newspaper & 1.8 \\
\hline
\end{tabular}

Use of internal tampons was indicated by $28.7 \%$. The reasons for the specific choice was comfort (40.5\%), the fact that it was inexpensive (21.9\%), and the level of protection provided by internal tampons (11.5\%). Some $(<10 \%)$ participants indicated that they would adapt the type of protection according to their social activities and the intensity of the menstrual flow at a specific point during menses.

The frequency of changing to clean sanitary protection ranged from more than six times per day (10\%) to once daily (6.8\%). The majority of the group (58.4\%) indicated that they change their sanitary protection between two and four times per day. Only $7.2 \%$ of the respondents indicated that they re-used sanitary protection.

Practices of cleaning hands and genitals were also investigated. The majority of the group (79.2\%) reported that they washed their hands before and after changing their sanitary protection. Asmall group (12.9\%) reported that they do not specifically wash their hands when changing sanitary protection. The most frequently used method of the cleaning of hands and genitals was with soap and water (80.6\%) while the remainder of respondents used water only. The reported frequency of cleaning the genitalia was: more than two times per day (36.9\%), twice a day (44.4\%), once a day (13.3\%) and less than once a day (5.4\%), again mostly with soap and water. When other methods of cleaning were explored, a group of women (8.2\%) indicated that they used Dettol as a cleaning agent. Reasons for cleaning practices were listed as being hygiene, comfort, and to be odour free. When asked about the place where sanitary protection is changed, only $22.6 \%$ reported that they could use a bathroom. The most frequently utilised place (31.2\%) was an outdoor toilet.

\section{Sexual practices}

Sexual practices that could increase a woman's risk of developing cervix cancer were investigated. The first practice mentioned by the majority of the respondents, was the age of sexual debut. The majority of the group (74.2\%) experienced sexual debut before the age of 20 years. Of this group, $19.3 \%$ reported sexual activity at 15 years or younger. Being sexually active during the period of the study, was reported by $89.6 \%$ of the group. In the sexually active group, 26 individuals were younger than 20 years of age. Multiple partners were only reported by $16.2 \%$ of the group.

With regards to the practice of having sexual intercourse during menstruation, only $14.1 \%$ of the group reported in the affirmative. Of concern however, is that the highest frequencies were reported in the youngest age groups. In the $<20$ age group, $26.9 \%$ responded positively, compared to just $13.8 \%$ of the $20-29$ age group and $16.9 \%$ in the $30-39$ age group.

Using condoms during sexual intercourse for protection is still low. Figure 3 presents the age variations in condom use. The highest use (56\%) was reported by the 20-29 age group with the lowest condom use (36.1\%) in the 30-39 age group. Less than half of the teenager group reported using condoms.

Only a small group (6.5\%) reported using a female condom. Other methods of sexual protection reported by a few individuals (<5\%) include: a cord covered with "muti" tied around the waist, and drinking herbs before intercourse. 
The reasons given for using male condoms during sexual intercourse are presented in Figure 4. Of the group (45.9\%) who do use condoms, $73.4 \%$ use condoms to prevent transmission of an infection and $18 \%$ do so to prevent pregnancy. Of concern is that $48.7 \%$ of the group $(n=128)$ who reported not using condoms knew that condoms could protect them from the transmission of infections, and one in ten knew that condoms prevent pregnancy. Forty percent (40\%) of the group who reported to use condoms did not know the reason for using a condom during sexual intercourse. The majority of this 'no knowledge' group (65.6\%) is above 30 years of age.

With regards to oral or injectable contraception, half of the respondents (49.5\%) use injectable contraception with $19 \%$ using oral contraception.

A sensitive issue, namely the level of wetness or dryness of the vagina during sexual intercourse, was included in the questionnaire. Forty percent (40\%) did not answer the question. Of those who responded,
$45.5 \%$ indicated a preference for a dry vagina. Practices reported to dry the vagina included smearing "muti" using various forms of traditional methods and applying herbs and powders.

Fifty percent (50.9\%) of the women indicated that their partner was circumcised.

\section{DISCUSSION}

The results highlighted several health related risks that could increase the women's chance to develop cervix cancer. The risks are inherent to the socio-economic environment, the level of knowledge and awareness of cervix cancer, and to practices during menstruation.

Many of the women in the sample are socially and economically disadvantaged. Unemployment is high with $62.7 \%$ of the study sample being unemployed and just more than half having piped water in the house with a flush toilet. Almost $40 \%$ lived in informal housing. De Sanjose, Bosck, Munoz and Shah (1997:309) indicate

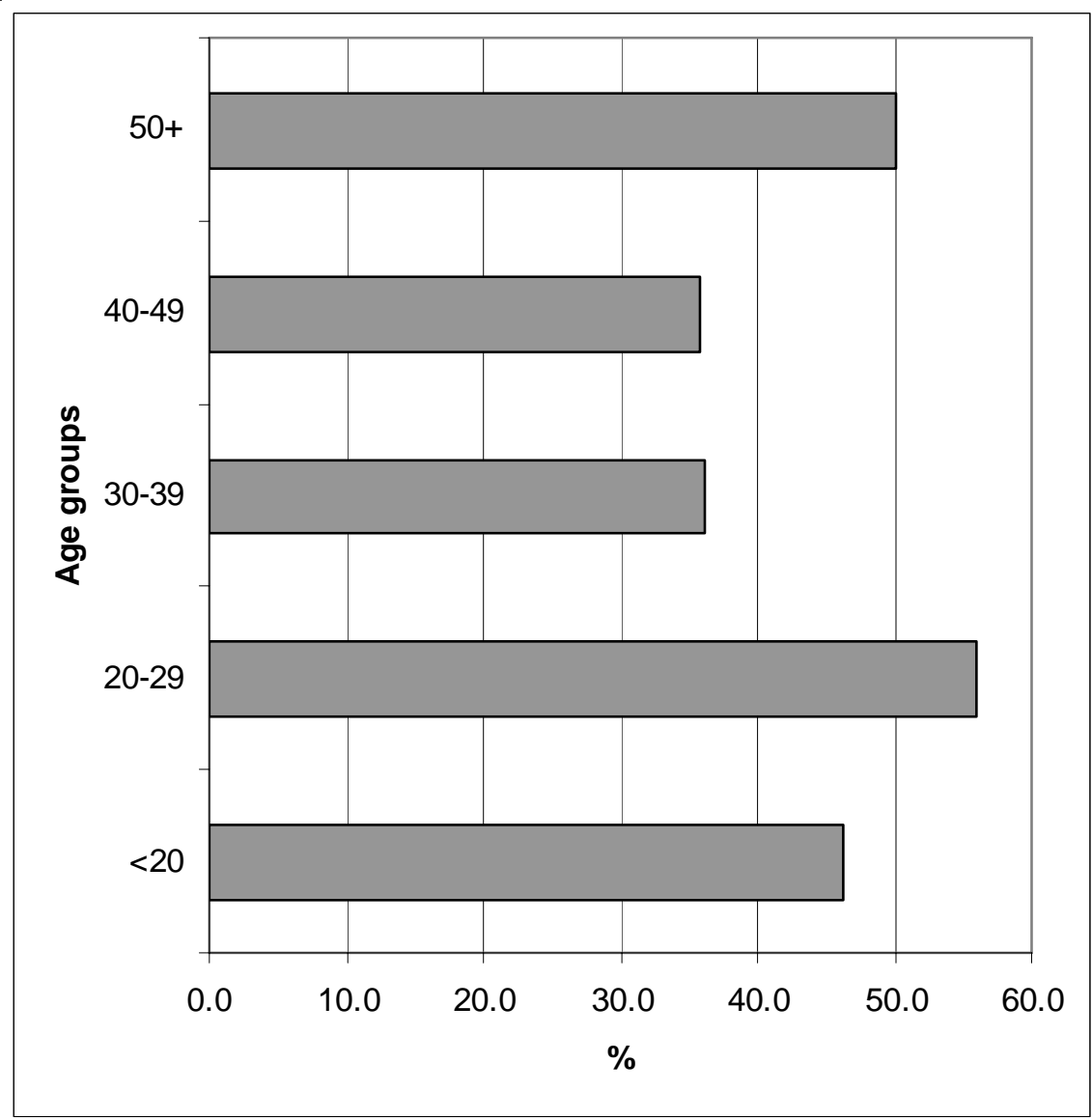

Figure 3: Age groups and condom use 


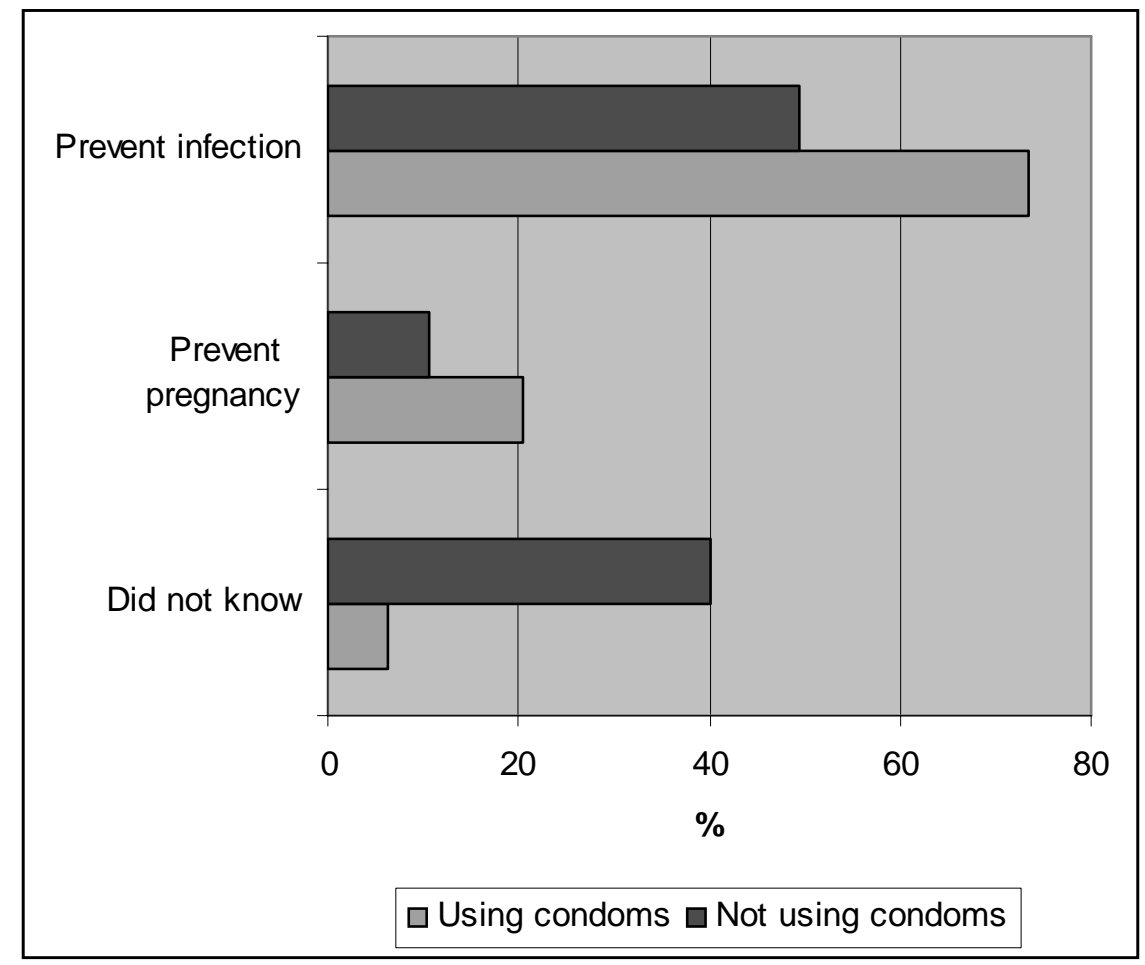

Figure 4: Condom use and knowledge of reasons for condom use $(n=128)$

that cervix cancer is more frequent in developing countries than developed countries but that in all areas, it is more frequent among women of low socio-economic status. In addition, women with no schooling had a threefold to fivefold higher risk to develop cervix cancer.

Health related risks were found to be directly influenced by the women's knowledge about cervix cancer and the Pap smear. Less than half of the group $(44.8 \%$ and 49.8\%) knew about cervix cancer and a Pap smear. It must not be assumed that these figures represent approximately the same group of women. Some of the women who were aware of cervix cancer did not know that a Pap smear was used to diagnose cervix cancer. The same situation applied to those who were aware of a Pap smear. Not being knowledgeable about either of these important concepts and understanding their role in cervix cancer leaves the women in a self-care deficit. Herrero et al. (1990: 263) report that not having a Pap smear increased a woman's relative risk to develop cervix cancer to 2.5. In support, Wiellensiek, Moodley, Moodley and Nkwanyana (2002:376) write that the value of screening for cervix cancer has been proven and that screening has decreased the incidence and mortality by $80 \%$.

In terms of the age groups, half of the women in all the age groups did not know of the existence of cervix can- cer. In a seperate study, Pillay (2002:103) reported that one fifth of the respondents were not aware of cervix cancer and more than half were not aware of a test to detect cervix cancer. The author also reports lower awareness levels in older and rural women. This deficit of knowledge, specifically among older women, could be responsible for the lack of appropriate health care role models for younger women.

Approximately three in ten women had knowledge of some of the risk factors for cervix cancer. An early sexual debut and sexually transmitted infections are the best known risk factors, with the role that diet could play the least known. These risk factors are accepted risk factors for cervix cancer in literature (Herrero et al. 1990:263, De Sanjose et al. 1997:310; Reid, 2001:299). These results indicate however, that the knowledge did not necessarily influence the women's behaviour. An early sexual debut was reported by $74.2 \%$ of the group and a high percentage (88.5\%) of those younger than 20 years of age were sexually active during the period of the study.

In addition, the practice of having sexual intercourse whilst menstruating was also more prevalent among the younger age groups. Ben-Noun (2002:99) reports several reasons why intercourse during menstruation increases the risk of sexually transmitted infections 
and by extension, cervix cancer. Some of these factors are the loss of the cervical plug during menstruation; the presence of iron in the menstrual blood; a premenstrual peak of oestrogen; and the activity of secretory cells during menstruation that could host the human immunodeficiency virus and increase the risk of female-to-male transmission.

Condom use is still low (45.9\%) in all age groups. Of concern is that almost half of the group who chose not to use condoms knew that condoms could protect them against the transmission of infections. A large percentage (40\%) reported that they did not know why they should use a condom. These findings support the fact that being knowledgeable does not necessarily positively influence the behaviour of a person.

Concerning the early signs of cervix cancer, interesting facts became apparent. Abnormal bleeding is generally not considered as a sign that something is wrong. An increased vaginal discharge is taken more seriously, possibly due to the relationship with sexually transmitted infections. A small group indicated that they would consider pain to be serious. It is clear that the women are not knowledgeable about early signs and they had a misconception regarding pain as a symptom of cervix cancer. Abnormal bleeding, a clear and distinctive early symptom of cervix cancer, is disregarded. A clear knowledge deficit existed in the group of women.

Practices during menstruation reported by the study sample, indicated several risks. Materials used for protection during menstruation could contribute to heighten the risk of infections. Irinoye, Ogungbemi and Ojo (2003:43) report that these practices are potentially harmful. The re-use of washed cloths is particularly risky as the human papillomavirus has been detected in menstrual blood and vaginal discharge (Tong, Chan, Chow, Yu, Leung \& To, 2003:140). The majority of the group reported good hygiene practices in terms of the washing of hands and genitalia. A small group of, less than two in ten of the respondents however, reported not washing their hands, or washing their genitalia less than once a day.

The practice of drying the vagina during sexual intercourse is also inherently risky, not only in terms of what is used to dry the vagina but also with regards to the potential of creating lacerations and abrasions which in turn provide an entry point for bacteria and viruses. Any behaviour that increases the risk of human papillomavirus transmission likewise increases the woman's risk of developing cervix cancer.

\section{LIMITATIONS}

The generalisability of the study is limited due to the use of a convenient sample. Also, the sensitivity of the topic might have caused some women not having responded to some of the questions. The questions about levels of knowledge were dependent on the recollection of the respondent which could result in a level of bias.

\section{RECOMMENDATIONS}

Recommendations emanating from the study are as follows:

- A deficit in knowledge exists in terms of cervix cancer and the risks inherent to menstrual and sexual practices. Registered professional nurses should not accept that a woman who knows about cervix cancer is knowledgeable about a Pap smear nor the risks factors nor early signs and symptoms of cervix cancer.

- The relationship between abnormal bleeding, cervix cancer and pain should be taught as part of health promotion intervention strategies to educate women regarding cervix cancer.

- In their supportive-educative role, the registered professional nurse should use every teachable moment available to educate young women regarding the risks they face due to commonly used sexual and menstrual practices. Young women below 20 years of age are at particular risk for contracting a sexually transmitted infection and cervix cancer in later life due to the lack of knowledge regarding the risk factors related to cervical cancer specifically human papillomavirus and cervix screening.

- Registered professional nurses should promote the self-care philosophy and encourage clients to take responsibility for their own health in the primary health care setting. To enable the registered professional nurse to have a community-specific message, she needs to know the level of knowledge of women in the community regarding cervix cancer and their sexual and menstrual practices. 


\section{CONCLUSION}

It was evident that a large number of women included in the study sample were at risk of contracting a sexually transmitted infection or cervix cancer in later life due to a lack of knowledge and awareness about cervix cancer as well as specific menstrual and sexual practices. Self-care is based on a solid foundation of knowledge. The transmission of knowledge should be done in such a way that it also manifests in healthy behaviour by women. Only if the woman is knowledgeable to such an extent that she is also willing to act and change her behaviour, can her health be promoted and will she be able to take responsibility for her own health. The registered professional nurse, in fulfilling the supportive-educative role, is uniquely situated to bring about this transformation to promote life, health and well-being in women.

\section{REFERENCES}

BEN-NOUN, LL 2003: What is the biblical attitude towards personal hygiene during vaginal bleeding? European Obstetric and Gynecological Reproductive Biolology, 106(1):99-101. BERBIGLIA, VA 2006: Orem's self-care deficit nursing theory in practice. (In: ALLIGOOD, MR \& TOMEY, AM (eds.) 2006: Nursing Theory; $3^{\text {rd }}$ edition. St. Louis: Mosby; pp 55-282).

BRANT, J 1999: Cervical cancer. (In: MIASKOWSKI, C \& BUCHSEL, P. Oncology nursing: Assessment and client care. St. Louis: Mosby: pp 657-688).

BURNS, N \& GROVE, SK 1997: The practice of nursing research conduct: Critique \& utilization. Philadelphia: WB Saunders.

CANCERASSOCIATION OF SOUTH AFRICA (CANSA) 2004: National cancer registry. Available at: http:/www.cansa.co.za/ registry.asp. (Accessed on 5 August 2004).

CASSIDY, J; BISSETT, D \& SPENCE, RAJ 2002: Oxford Handbook of Oncology. Oxford: Oxford University Press.

CASTELLSAGUE, X; BOSCH, FX \& MUNOZ, N 2003: The male role in cervix cancer. Salud Publica Mex, 45(Suppl 3):S345-353.

DE SANJOSE, S; BOSCK, FX; MUNOZ, N \& SHAH, K 1997: Social differences in sexual behaviour and cervix cancer. IARC Scientific Publication, 138:309-17.

DRAKSHAYANI, DK \& VENKA, RP 1994: A study on menstrual hygiene among rural adolescent girls. Indian Journal of Medical Science, 48(6):139-143.

EDMOND, CB 2003: The reproductive system. (In: Alexander, MF; Fawcett, JN \& Runciman, PJ (eds.). Nursing practice: Hospital and home; $2^{\text {nd }}$ edition. Edinburgh: Churchill Livingstone; pp 59:86.) GICHAGA, SP 2000: Strategies for addressing management of growing up and sexual maturation among girls and boys and menstruation practices in primary schools in Nairobi and Bondo Districts in Kenya. Forum for African Women Educationalists, Kenya Chapter. Available at: http://www.fawe.org/publications/ (Accessed 31 January 2004).

HERRERO, R; BRINTON, LA; REEVES, WC; BRENES, MM; TENORIO, F; DE BRITON, RC; GAITAN, E; GARCIA, M \& RAWLS, WE 1990: Sexual behaviour, venereal diseases, hygiene practices and invasive cervical cancer in a high-risk population. Cancer, 65(2):380386. Available from http://www3.interscience.wiley.com/cgi-bin/ fulltext/112686889/PDFSTART. (Accessed on 17 September 2005). IRINOYE, OO; OGUNGBEMI, A \& OJO, AO 2003: Menstruation: knowledge, attitudes and practices of students in Ile-lfe, Nigeria. Niger Journal of Medicine, 12(1):43-51.

LEEMAN, P 2002: Women still in the dark about cervical cancer. Available at: http://www.hst.org.za/news/20021105.

MSIZA, I 2005: Interview by researcher with professional registered nurse in charge of mobile clinic in Soshanguve regarding sexual practices reported to her during consultations. Pretoria. O'BRIEN, PMS \& PIPKIN, FB 1999: Introduction to research methodology. London: RCOG Press.

PILLAY, AL 2002: Rural and South African women's awareness of cancers of the breast and cervix. Ethnic Health, 7(2):103114.

REID, J 2001: Women's knowledge of Pap smears, risk factors for cervical cancer, and cervical cancer. Journal of Obstetric, Gynaecological \& Neonatal Nursing, 30(May):299.

SCHIFFMAN, M \& CASTLE, PE 2003: Human papillomavirus: Epidemiology and public health. Archives Pathology Laboratory Medicine, 127(8):930-4.

SHEPHERD, J; WESTON, R; PEERSMAN, G \& NAPULI, IZ 2000: Interventions for encouraging sexual lifestyles and behaviours to prevent cervical cancer. Cochrane Database of Systemic Reviews, (2):CD0001035. Available at: www.cochrane.org/reviews (Accessed on 20 February 2007).

TONG, TR; CHAN, OW; CHOW, TC; YU, V; LEUNG, KM \& TO, SH 2003: Detection of human papillomavirus in sanitary napkins: $A$ new paradigm in cervical cancer screening. Diagnostic Cytopathology, 28(3):140-141.

WALLER, J; MCCAFFERY, K; NAZROO, J \& WARDEL, J 2005: Making sense of information about HPV in cervical screening: A qualitative study. British Journal of Cancer, 92(2):265-70. WIELLENSIEK, N; MOODLEY, M; MOODLEY, J \& NKWANYANA, N 2002: Knowledge of cervical screening and use of cervical screening facilities among women of various socioeconomic backgrounds in Durban, South Africa. International Journal of Gynaecological Cancer, 12(4):376-382 . 